\title{
COMPARATIVE ANALYSIS OF THE FLOODS IN PRAGUE (CZECHIA) AND IN SEVILLE (SPAIN): SEEN FROM THE GEOGRAPHICAL VIEWPOINT
}

R. Baena Escudero, I. Guerrero Amador, B. J a n ský : Comparative analysis of the floods in Prague (Czechia) and Seville (Spain): seen from the geographical viewpoint. - Geografie-Sborník CGS, 111, 3, pp. 326-340 (2006). - The urbanization pressure upon the areas originally endangered by floods has increased, creating a new imbalance between the city and the river. The relationship to the various strategies that are being used to prevent the predictable flood risk in Prague and Seville, constitute the main topics of the following article. Authors analyze two very different drainage systems - the Vltava river in Czechia with temprate snow-rain climate versus the Guadalquivir river in the south of Spain with subtropical rain climate. The general hydrological properties will be compared as well as the highly different morphohydrology of the specific flood areas close to the cities of Seville and Prague.

KEY WORDS: flood risk - hydrology - Vltava river - Guadalquivir river - comparative analysis - historical floods - flood protection strategies..

The presented research was funded by the Research Plan MSM 0021620831 "Geographical Systems and Risk Processes in Context of Global Changes and European Integration" of the Czech Ministry of Education and Research Project VaV-SM/2/57/05 "Long-term changes of river ecosystems in floodplains affected by extreme floods" of the Ministry of Environment of the Czech Republic which is fully appreciated by the authors.

\section{Introduction, goal and methods}

During the last two decades in the Czechia and Spain, important changes to the social system have taken place. These resulted, among other things, in new approaches by public administration to natural systems in general and to the rivers in particular. The rivers represent clear examples of complex ecosystems deeply altered by human activity. Undoubtedly they are of considerable economical, sociocultural and ecological importance for the cities built on their shores (Garzon et al. 1990; Martinez et al. 1991; Peiry, Nouguier 1994; Klingeman et al. 1994; García y Baena 1997). Despite the traditional as well as current danger of floods with catastrophical consequences, the areas immediately along the shores of a river are not always included in territorial planning. Thus, a conflicting borderline area between the socio-economical and natural spheres has been created. Factors that influence the river-basins and their surroundings became the top priority in the fight against floods. This, to a larger extent, explains why river streams in cities are so artificial and at the same time almost marginal, without much importance. Regardless of our feelings about it: we had 
succeeded in reducing the frequency and volume of floodings leading to increased safety for human activities. At the same time, urbanization pressure upon the areas originally endangered by floods has also increased, creating a new imbalance between the city and the river. In such an imbalanced system, the risk of potentially dangerous hydrological events, now extreme ones, is growing again.

The relationships between the above mentioned elements and especially the relationship to the various strategies that are being used to prevent the predictable flood risk in Prague and Seville, constitute the main topics of the following article. It is based upon two key assumptions for the arrangement of the city landscape located directly ashore a river. The first principle is that floods are not disasters. They are natural events reacting to extreme but natural processes in the river systems. That is why flooding lowlands and similar morphological shapes exist (Ward 1978, Mateu 1990, Díaz y Baena 1999). Therefore, it is the interference of humans and their settlement on the shores of rivers, that causes and increases the flood risk (Parker, PenningRowsell 1982; Baena y García 1995; Langhammer 2003). The second principle says that we have to approach a risk that has been created in this manner as a problem between the interaction of society and the environment. Variable factors of time and area are included, depending on other participating forces. This second principle also depends on the level of socio-technological development, on the city's spatial and infrastructural needs (Guerrero y Baena 1996), or from the climate change and the corresponding river reaction in regard to water volume and sedimentation (Schum 1977, García y Baena 1997).

To illustrate these ideas, this article analyzes two drainage systems, very different due to location: 1 . the Vltava river, representing the headwaters, of the Elbe river basin in Czechia and 2. the Guadalquivir river, the main collection stream in the south of Spain. The second major difference is the climate - temperate continental climate versus Mediterranean climate - and the third consists of hydrological properties - temperate snow-rain climate versus subtropical rain climate. In this article, the general hydrological properties will be compared as well as the highly different morphohydrology of the specific flood areas close to the cities of Seville and Prague. We will analyze the distribution and volume reached by floods in these two cases, their consequences resulting from identified morphohydrological elements, and construction projects realized within their immediate surroundings.

The publicly accessible hydrological data has been acquired from UNESCO (1971-1985). Additional data valid for floods has been added - provided by Vanney (1970), Drain et al. (1971) and Guerrero y Baena (1998) in the case of the Guadalquivir river and Janský (2004), Daňhelka (2004) as well as Baena et al. (2004) for the Vltava river. The physiography of each of the city's position in relation to the development of the geometrical variables of the river bed and its stability or instability has been acquired by geomorphological terrain investigation and by the use of satellite orthoimages.

\section{Hydrology of the rivers Vltava and Guadalquivir}

The amount of rainfall registered in Czechia during August 2002 was undoubtedly an exceptional situation given the geographical size of the 
Tab. 1 - Hydrological properties of the Vltava and Guadalquivir rivers

\begin{tabular}{|l|c|c|c|c|c|c|c|c|c|c|}
\hline River & Profile & $\begin{array}{c}\text { Area of } \\
\text { River } \\
\text { basin } \\
\left(\mathrm{km}^{2}\right)\end{array}$ & $\begin{array}{c}\text { Discharge } \\
\left(\mathrm{m}^{3} / \mathrm{s}\right)\end{array}$ & $\begin{array}{c}\text { Qmax } \\
\text { average }\end{array}$ & $\begin{array}{c}\text { Qmin } \\
\text { average } \\
\left(\mathrm{m}^{3} / \mathrm{s}\right)\end{array}$ & $\begin{array}{c}\text { Coef. } \\
\text { var. } \\
\text { annual }\end{array}$ & $\begin{array}{c}\text { Discharge } \\
100 \\
\left(\mathrm{~m}^{3} / \mathrm{s}\right)\end{array}$ & $\begin{array}{c}\text { Discharge } \\
500-1000 \\
\left(\mathrm{~m}^{3} / \mathrm{s}\right)\end{array}$ & $\begin{array}{c}\mathrm{P} \\
(\mathrm{mm})\end{array}$ & $\begin{array}{c}\mathrm{T} \\
\text { July } \\
\left({ }^{\circ} \mathrm{C}\right)\end{array}$ \\
\hline Vltava & Praha & 26730 & 148 & 662 & 50 & 0.30 & 4020 & 5200 & 525 & $<20^{\circ}$ \\
Guadalquivir & Alcalá & 49900 & 185 & 1306 & 32 & 13.8 & 8000 & 11000 & 585 & $>20^{\circ}$ \\
\hline
\end{tabular}

afflicted area $\left(100000 \mathrm{~km}^{2}\right)$, the persistence of raining (August 6th to 15th, 2002) and it's intensity throughout all of Central Europe. Such a meteorological occurrence is caused by continual progress of occlusion fronts strengthened by the presence of warm and damp air streams acting together with the influence of mountains. All this created a certain phenomenon similar to the extreme autumn rains in Mediterranean Spain or to the continuous storms from the South-West in the lowland of the Guadalquivir river. Here, rainfall values, higher than the above mentioned ones in Central Europe, cause floods of a larger extent, although in a smaller area and with a lesser danger to the society. The reason for this is probably that centuries of adaptation have made the human ecosystems at least partially prepared and more able to protect itself from the dramatic consequences (Gil Olcina, Morales 1989).

This event from the summer of the year 2002 and now also from the summer of 2005, assumes revision of the general planning of stream regulation in the temperate climate zone. Especially for the rivers with rare fluctuations within one year $(0,3$ for Vltava, 0,2 for Rhein, etc. ... compared to 13,8 for the Guadalquivir river) and reduced flood stage $\left(1500 \mathrm{~m}^{3} / \mathrm{s}\right.$ average, $3700 \mathrm{~m}^{3} / \mathrm{s}$ for hundred-year water of the Vltava river) in relation to the maximum annual flow rate (Qmax. $\left.=697 \mathrm{~m}^{3} / \mathrm{s}\right)$. Particularly in comparison with Mediterranean rivers such as Guadalquivir (Table 1), which is being considered a large stream, given the up to seven-times difference between it's coefficient attained by the maximum average flow rate and the sixty-times larger flow rate value during the millennial water such as on 1. January 1968. This millennial flow rate is estimated to have been about $12000 \mathrm{~m}^{3} / \mathrm{s}$, with 63000 victims and 6000 houses as well as the majority of wall paintings destroyed, it is the largest catastrophe of it's kind in the history of Europe (Drain et al. 1971, Bosch 1988, Albentosa 1989).

In comparison, the values exceeding $5000 \mathrm{~m}^{3} / \mathrm{s}$ measured at the Vltava river in the summer, corresponding to values for ten-year floods at Guadalquivir (Vanney 1997), have raised great agitation regarding their causes. The influence of climatic changes, incorrect landscape usage or nonfunctioning Central European structural protection systems, for example insufficient shore dams and reservoir systems for the regulation of the main stream, are being discussed. The solution - surface geometry of the potentially flooded area has to be judged from the hydrogeomorphological and historical viewpoints - probably still lays in distant future for many rivers and is literally impossible for the problematic ones.

2.1 Important floods on the Vltava river and their characteristics

The Vltava river can be characterized by snow-rain mode with spring melting and intense orographical showers during the summer. A series of 


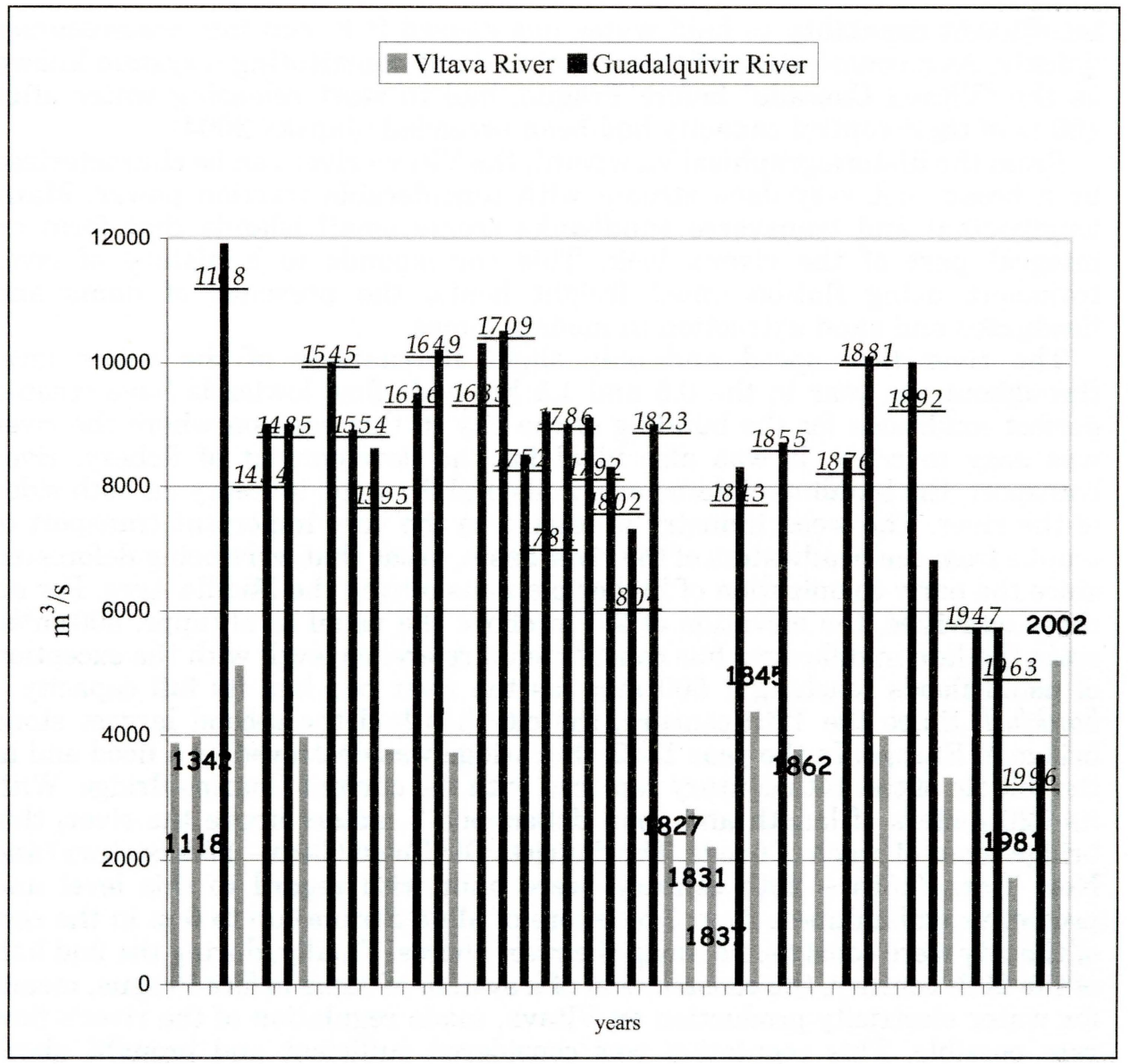

Fig. 1 - Main floods in the history of the city of Prague (Vltava River) and Seville (Guadalquivir River)

exceptional floods in the history of the Vltava river in Prague since 1827 shows a tendency common for European rivers; reduction in the number of exceptional floods during the last two centuries (Petts et al. 1989) with the largest number of floods in the second half of the 19th century (Fig. 1), especially in the winter period, which has during the last fifty years become warmer, with a lesser amount of snow.

The most destructive floods ever registered have been single cases, such as in March of the year $1845\left(4360 \mathrm{~m}^{3} / \mathrm{s}\right.$ or $7.07 \mathrm{~m}$ height above the usual water level in Prague), in the year 1890 (3 $860 \mathrm{~m}^{3} / \mathrm{s}$ and $6.42 \mathrm{~m}$ height), where three bridges were destroyed, and in the middle of the 20th century in the year 1940 (3 $\left.300 \mathrm{~m}^{3} / \mathrm{s}\right)$. Unexpected river flow in August 2002, with a flow rate of $5160 \mathrm{~m}^{3} / \mathrm{s}$ and a height never reached before, $7.82 \mathrm{~m}$, represents a serious warning about the disturbance of geomorphic limits in the river system of this region. The fact that this catastrophe occurred in summer, in a period with the lowest expected rainfall volume, highlights its significance as within only 10 days, the rainfall had reached 40 to $60 \%$ of the total annual rainfall for the South Bohemian area. The other serious fact to note is that the landscape's 
insufficient capability to hold water has caused it to run into watercourses quickly. As a consequence of this, all nine dams constituting a system known as the "Vltava Cascade" before Prague, had to start releasing water after $100 \%$ of their control capacity had been exceeded (Janský 2004).

From the historiographical viewpoint, the Vltava river can be characterized by a broad, not very deep stream with considerable traction power. Many longitudinal and transverse sandbanks create small islands that form an integral part of the river's look. This corresponds to a history of river transport using flat-bottomed freight boats, the presence of dams and floodgates and sand extraction in modern times.

The river flow speed and only slight fluctuations of the water level throughout the year in the 0.5 and $1.5 \mathrm{~km}$ wide flow lowlands have created perfect conditions for the building of the city in this position where the river was easy to cross. It was also ideal for the development of fishery, river transport, the building of dams and mills and for wood industry on both sides of the river. The wood industry is related to the very important transport of trunks from the headwaters of the river basin, areas that were being deforested since the early colonization of higher plateaus during the Middle Ages. For all these activities, the elevation of $2.5 \mathrm{~m}$ above the usual level (appr. $300 \mathrm{~m}^{3} / \mathrm{s}$ ) since the late middle ages has constituted a reference level, with the exception of usual floods reaching $1500 \mathrm{~m}^{3} / \mathrm{s}$, as the river bed had its full capacity bankfull. Since the 12th century, the city has had the second largest stone bridge in Europe. In the year 1342, this bridge was destroyed by a flood and in the middle of the 14th century replaced with the current Charles Bridge. With its 520 meters of length and span deflections 7 meters above the river, this bridge is out of reach of floods. The districts Old Town (14th -17 th century) and New Town (18th - 20th century) were built with regard to this level and protective embankmets from $3 \mathrm{~m}$ (shore of Malá Strana) up to $6 \mathrm{~m}$ in the rest of the city were constructed along the river shores. Finally, during the 2nd half of the 20th century, the construction of a system of dams before Prague, meant for water electricity production on Vltava, made regulation of the river's flow rate possible. This regulation was considered sufficient and brought about enormous integration of urban elements into the river landscape.

\subsection{Important floods on the Guadalquivir river and their characteristics}

In the case of Seville, the river's morphogenesis originally included the complete space without grass topography, with a low elevation above sea level (between 6 and $13 \mathrm{~m}$ ). At the right and left edge, it is demarcated by slopes that were created above the last Quaternary irrigation fields, on marly and sandy basis, which creates the Aljarafe slope. It is a lowland, on the average $5 \mathrm{~km}$ wide, with the Guadalquivir river flowing through the middle, with low longitudinal fall $(0.045 \%)$, of meander-like shape, with frequent aquosity fluctuations during different parts of the year. Minimums occur in September $\left(32 \mathrm{~m}^{3} / \mathrm{s}\right)$ and maximums in spring $\left(300-400 \mathrm{~m}^{3} / \mathrm{s}\right)$, not exceeding the full capacity of the river bed estimated to be about $900 \mathrm{~m}^{3} / \mathrm{s}$ (Vanney 1970).

From the hydrological viewpoint, this wide space was great for natural drainage needs, with average flow coefficient, estuary dynamics in the Seville area, high time irregularities and great floods, catastrophic for human activity on the river's shores. These floods generally reach from 1500 up to $12000 \mathrm{~m}^{3} / \mathrm{s}$ (thousand-year water). Until the middle of the last century, they 
were regulated by the functioning of numerous branches and vacant meanders located in the lowland.

From the values measured in Seville's harbor that show the height reached by floods (Fig. 1), an increase in the number of floods towards the end of the 18 th century and in the second half of the 19th century is visible. The floods in the 19th century strongly exceeded the usual level: in the year 1892 (more than $10 \mathrm{~m}$ ), repeated after 100 years, or in the years 1168 and 1709 , with maximum flooding in 500-1000 years and a level rise of 11 to $12 \mathrm{~m}$. The last important flood at the Guadalquivir river, before the completion of the hydroelectric plants in the eighties, happened in February 1963 . With $5700 \mathrm{~m}^{3} / \mathrm{s}$, it caused considerable damage to the inhabitants of the lowland between Córdoba and the swamps. These are now probably the maximum values that can be expected, because of the regulation stage ensured by dams in the river's drainage basin.

In the past, the city has tried to adapt to these exceptional events by using various settling strategies. In Romanic times settlement in the lowland was important for agriculture and the possibility to use the river for ship transport. Buildings were situated $10-12 \mathrm{~m}$ above the river, with the exception of harbor buildings which were placed at the side branches of the Guadalquivir river. During the Middle Ages and in the modern times, the increasing number of inhabitants has led to the occupation of a part of the flood lowland. Since the 12th century, the people here defended against the river using broad and high Almohad walls. In floods, Seville remained isolated from the rest of the area for weeks. The city's surroundings behind walls (Triana, Macarena, San Bernardo), or inside walls, were stricken because of rain water. Such was the situation until the end of the 18th century. At that time, insufficient river depth for ship passage and frequent floods prevented normal functioning of harbor activities. So people began work on the following large protective projects:

1. The building of embankments, 10 and $11 \mathrm{~m}$ high, along the river stream in the harbor area. At first at the edge of the historical centre (18th-19th century.) and later also in the Triana suburb. At the same time, the first solid bridges were built (the Triana bridge 1852; the San Telmo bridge 1931) both 12 meters above water.

2. The river was straightened, the meanders shortened and the main stream behind the city of Seville was deepened (18th-20th century). The river's axis was shortened by more than $40 \mathrm{~km}$ and its bed was deepened considerably, so that drainage capacity increased.

3. Artificial moving of the river towards the west, outside the city (Corta de Tablada in the year 1926, Canal de Alfonso XIII, silt deposition at the Chapina and Los Gordales shores), while harbor activity inside the city remained in the inner harbor controlled by a lock. Higher protective walls, above the thousand-year water level, were added.

4. The regulation of a large part of the stream in the river basin by the building of many dams at Guadalquivir (Alcalá del Río, Cantillana, Puente Sifón, Peńaflor) and it's main affluents with 18 functional spillway dams and a capacity of $1500 \mathrm{Hm}^{3}$ in the first half of the 20th century; the 25 additional dams have quadrupled the total capacity since the year 1960 , so that the theoretical values necessary for general hydrological control were achieved.

5. Finally, the realization of the last of the corridors (La Cartuja) meant definite removal of the functional river from the immediate vicinity of the city through the sluicing of shores in the San Jerónimo and Triana 
quarters. These measures extended the usable space meant for the World Exhibition in the year.

The result is that the functional river flows outside the city in a designated water channel, into which the water is being drained. All this, together with long droughts in the 80 s and 90 s has created a false belief that all flood risks have been removed, both by the authorities as well as the public. Doubts were cast on this as a flood of smaller volume but larger height caused by limited space for water spreading came in winter of the year 1996.

\section{The flood at the Vltava river in the year 2002 and it's consequences for the city of Prague}

From the geomorphological point of view, the river section of Vltava in Prague corresponds to the meandric model, with a low sinusoid, wide stream of medium fall and mixed bottom (gravel and sand), which passes through a flood lowland limited by hill slops. This fact makes wide spreading of the flood maximums impossible. Instead, convergence and divergence of flood streams happens, depending on whether the river section is straight or incurvated, with natural or artificial obstructions.

As mentioned previously, the movement of continuous fronts from the Mediterranean sea in the summer of 2002 caused rainfall in the whole area of Central Europe and especially in South, West and Central Bohemia. Here, the rainfall volume from both fronts was so large that it reached $1.87 \mathrm{~km}^{3}$ in the river

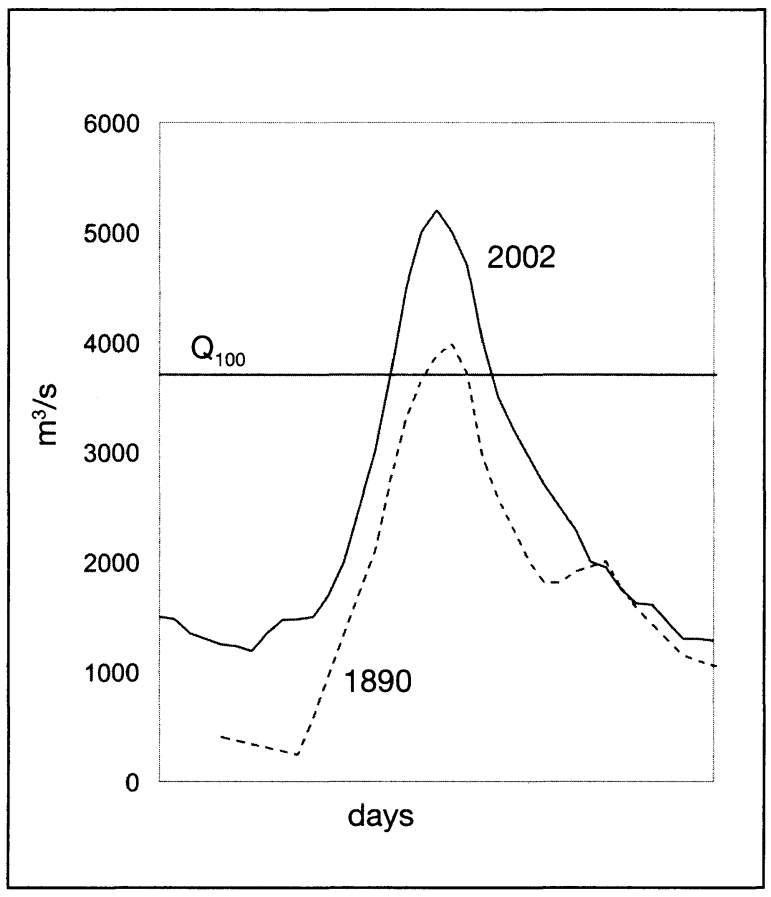

Fig. 2 - Comparison of hydrological maximums at Vltava River in the years 1890 and 2002 basin of Vltava in the first wave (August 7th-8th, 2002) and $2.77 \mathrm{~km}^{3}$ in the second wave (August 11th-12th). As a consequence of this, the river basin was completely saturated. This led to the exceeding of the retention capacity of the river's dam system by $8 \%$. After their opening, a flow rate of $5160 \mathrm{~m}^{3} / \mathrm{s}$, with estimated return once in 500 to 1000 let was created. The flood reached this point on August 14th at 12:00 (Fig. 2), with a maximum of $7.82 \mathrm{~m}$ in relation to the normal water surface. This is $1.4 \mathrm{~m}$ more than during the hundredyear water in the year 1890 . The water remained outside the water bed for 9 days, compared to 6 days in 1890 . The consequences were disastrous for Prague and its surroundings. Inhabitants 
including tourists had to be evacuated. Damages and losses were estimated to amount to EUR 2.5 billion.

In the area between Vyšehrad and Sedlec, different behavior of floods and differences in the damages caused, depend on the functionality of the following morphohydrological sections that can be distinguished from the South to the North.

\subsection{Section Vyšehrad - Letenské sady}

In this section, the stream is straight, with considerable deviations in width and terrain breaks in the profile that correspond to the location of islands. The stream has shores well-defined by historical protective walls, with the exception of areas with old mills, side islands or water energy usage (Kampa, foot bridge...). This has created a discrepancy in the water activity. The water is more active at the left shore (Vojanovy), while the jesep-walls or point bars in Josefov remain completely inactive because of the presence of the historical centre. In this section, the river has increased drainage capacity in the case of extreme floods, reduced only by the incurvation and meander between Josefov and Letenská. This region corresponds to the historical river sector of great historical value, dominated by the Charles Bridge and river islands such as Střelecký, Dětský and Slovanský, clearly integrated between the city and river landscape. This area is a very important focal point for tourism because of its characteristic open space. It connects the historical core with the castle and cathedral with amazing views of the city and many possibilities for entertainment and recreation. The consequences of the flood were partially reduced by the building of mobile dams up to $1.5 \mathrm{~m}$. However, these could not prevent the flooding of the underground subway system, so that city transport was paralyzed (more than 1 million subway users a day) and huge damage was incurred (10\% of the total damage) to machinery, the electric system and because of the evacuation and closing of the closest stations.

\subsection{Section Karlín - Holešovice}

Consists of the large Holešovice meander, which geomorphologically presented the main area for the spreading of the maximum water level values at the Vltava river, after the water crossed the narrowing in the previous part. In this section, stream divergence occurs. This has considerable influence upon the sedimentation of side point bars in Holešovice and the verticals in concave bench in Karlín. In addition, in the form of sand and mud (overbank deposits) in the mound presented by the old Rohanský island or in the form of clay (channel-fill deposits) in the vacant meander area in Karlín. In this section, the largest number of natural changes happened in the Holocene period including side potholes in the meander, widening and creation of the point bars at the right shore as well as neck cut off and stream vacation. Later changes were of antropical origin, related to the founding of harbors in Libeň and Holešovice or to the urban development of Karlín. As a consequence of this, great changes in the behavior of floor streams occured. These are now forced to hit the river's right shore. This has caused great damage during the last floods. This happens because of the continuing urbanization of the wide point bars in Holešovice. As their natural size is reduced, they make the passage of 
flood streams difficult, so that these deviate to the right shore. Then, the vacant stream in Karlín regains importance. Here we find the largest damage in the city, with the water level reaching its top value $(2 \mathrm{~m}$ above street level). This densely populated historical quarter had to be evacuated completely during the flood and the largest number of houses destroyed occured here. Numerous buildings above the point bars of Holešovice belonging to the top standard service and office complex (Rivercity Praga 2003) were endangered and are now evaluating the suitability of their position because of these risks.

\subsection{Section Trója - Bubeně}

Consists of an old branch of sedimentation decantation, with a peaceful stream outside shores, meeting again after Bubeneč. Today, because of the construction measures happening in the previous section, this is the only area for the flood spill in the city of Prague. This is the nearest flood lowland, the target of a still-growing flood pressure. Highly endangered is the Pelc Tyrolka area, downstream of the most intense flows from Liben and Maniny. The flooding of the Prague ZOO in the Trója area was especially dramatic, more than 1000 animals were evacuated and equipment near the river destroyed.

\section{Flood protection at the Guadalquivir river in Seville: space divided between the nature and the city}

Just like in the case of Prague, in Seville the Guadalquivir river and its flood lowland is the main geographical point of the city, one of the most important socioeconomic, natural, cultural and historical elements. Here the flood dynamic, because of its higher historical frequency and volume, has been the leading factor for the creation and development of the river space where the city is located and where the river presents the main spatial discontinuity. It is a territory where two large morphogenetic systems meet and encounter each other: on one hand the river system as a natural system with important risk factors in it's dynamics (the moving of meanders, leaving shores, floods, river conflux), and on the other hand the city, founded thanks to the river, which has during history overcome this dependence and has caused the largest disturbances man can bring about in their efforts to make maximum use of the territory.

Regarding the river, we have already mentioned its Mediterranean properties, characterized by irregularities, and the related fight against floods since the end of the 18th century with the help of large hydraulic construction projects that dominate today's lowland. These measures succeeded in achieving drastic reduction in the flood phenomenons and at the same time allowed the number of human inhabitants in this flow lowland to grow considerably. The river's spillage space for the case of extreme floods has been reduced to less than $25 \%$ of the original value. This lead to potentially higher water levels and a potential for extreme events.

It is now obvious that the flood in December 1996 with $3670 \mathrm{~m}^{3} / \mathrm{s}$ and a height of more than $7 \mathrm{~m}$ meant complete filling of the water corridor passing 


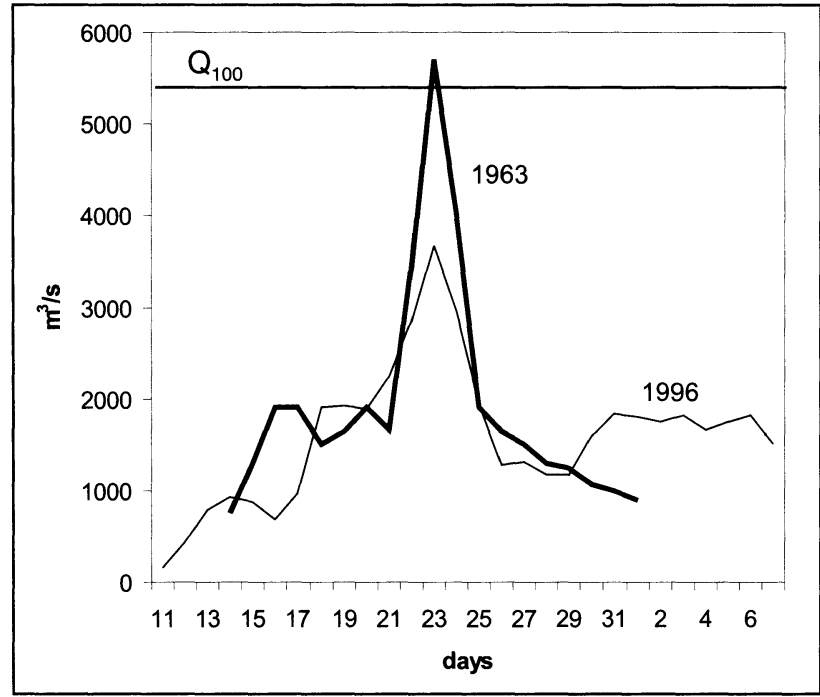

Fig. 3 - Comparison of the hydrological maximum of the Guadalquivir River in the years 1963 and 1996 through the Western part of the city. This was a flood of the second grade that occurred after a long dry period of six years and ended in the fall and winter of the year 1996 by $260 \mathrm{~mm}$ of rainfall within three months. These enduring rains were enough to saturate the river basin surface, to fill the dams completely and cause a flood comparable to the flood from the year 1963 . In Alcalá del Río, the water reached a flow rate of $5700 \mathrm{~m}^{3} / \mathrm{s}$. This was the last exceptional flood of the 20th century. In both cases, the flood

followed forced openings of the dams of the regulation system (Fig. 3). In the year 1996, the rising and falling was regulated more by the release of water from spillway dams upstream than by the intensity of rainfall. Regarding the city, no considerable damage has happened, besides damages to agriculture, irrigation devices and some roads. We can say that the flood-protection system designed in the previous century, which sets the look of the Guadalquivir river near Seville, does work. It consists of two streams relatively close to each other, independent of each other and with clearly divided function.

\subsection{Historical river; today inland harbor}

The inland harbour is the best-known region of the city and industry river. Its bed from San Jerónimo up to Los Gordales consists largely of the original river and also of the artificial channel dug during the Iberoamerican Exhibition in the year 1929, which now creates an inland harbor. In it's surrounding, we find the original face of a functioning flood lowland, now covered by city activity and buildings. We can only get to see the original version by performing archeological work on the ground designed for the construction of buildings or for the installation of infrastructure. This space is located at the edge of the river's morphogenesis and it's only disadvantages are the rising of the piesometric level of the alluvial water, which floods basements and garages, or the impossibility of rain water drainage. This isolation has finally allowed the river's integration into the city between fluctuations, with definite historical, recreational and visual importance. At the same time, this solution is good for the harbor function of the river, which is moving more and more towards the south, along the Alfonso XIII. channel, where the lock is the only mobile outlet of the protective system at the city's circumference. 
4.2 Functional river; hydraulic channel for the removal of flood water

A lesser-known part of the river, with a half-natural stream or 'living' river passes through the western part of the city, enclosed by the protective system of walls theoretically higher than the thousand-year water. The river's dynamics are influenced by the sea and also by the fluctuation aquosity caused by the time of the year and compensated by the large regulation capacity of numerous dams in the river basin. This is a changed area at the edge of the city, with only the need of minimum restoration of the natural environment of the shores to allow the inhabitants to use it for leisure and enjoy its natural potential. It's for good reason that the last city ground not covered by buildings can be found here. This ground still performs an important morphohydrological role in the spreading of the river's level during the exceptional floods. It includes such exceptional places as the La Isla Quijano Island and Playas de Tercia in the north or La Dehesa de Tablada in the south. There is strong urban pressure, especially on the Tablada islands. The land there has been purchased by a real estate agency and the authorities pursue it's overbuilding.

In any case, both streams with their shores represent the main and last open space factors of the Guadalquivir river on the city level as well as on the level of the metropolitan surroundings. For this reason, they should enjoy a lot of interest of public authorities to ensure their preservation. It would also be useful to utilize urban planning to preserve these shores as a green connecting corridor. The highways crossing the streams could be transferred to high viaducts crossing the lowland, so that territorial fragmentation of the area, which prevents it's integration into the city, would end.

\section{Conclusions}

From the morphological and hydrological viewpoint, the comparison of the city of Prague flooded in summer 2002 and the flood lowland of the Guadalquivir river in Seville again shows that it is the presence of humans and their activities on the floodable shores that causes natural events of this type, of catastrophic and exceptional character. We have to admit that situations such as the flow rate of $5160 \mathrm{~m}^{3} / \mathrm{s}$ at the Vltava river and $5700 \mathrm{~m}^{3} / \mathrm{s}$ at Guadalquivir can reoccur, especially if we take into account the origin of the imbalance and changes in river systems and their main control factor - the climate.

It would be necessary to evaluate the behavior of both rivers using integration strategies, not only structural, economically demanding ones as is the case of Seville. This means that the river area has to be planned and organized with regard to the natural morphohydrological dynamics that are typical for the river "free river space" and not the other way around. However, if the society has already ignored these warnings once, as our examples show, the reduction of these dynamic and instable areas to a minimum brings about an increased danger, which has to be accepted in spite of economic costs and material and human losses.

In the case of the Vltava river passing through Prague, there is a lack of structural investments of the volume found in Seville. These have until now 
not been known in Central Europe. It would be necessary to take into account that the protection of a certain river section for its historical and cultural value, as in the case of the section Vyšehrad - Letenské sady means to designate a natural space for the spreading of possible extreme floods downstream. With the help of project work, passing of the spilled river over the point bars in Holešovice would be made possible. A construction project would have to be limited there. Then, the spilled river would get back to the original vacant basin in the far-away lowland of Karlín. Further areas identified in this article as the closest flood lowland should only be used for purposes compatible with the possibility of high frequency of floods. So, we would no doubt avoid moving the problem to other parts of the river stream. With such plans, the Czech government has decided to introduce a flood protection programme, which includes the building of small dams in the river basin, thus increasing the regulation capacity. At the level of Vltava's city section, protection by raising the embankments in Karlín and by emergency plans prepared in cooperation with various authorities is being considered.

In case of the Guadalquivir river passing through Seville, the maximum level of structural measures would on the contrary require the current unstable balance between city and river presented by the lowland to be maintained. For this, the existing closest lowland next to the half-natural channel of the Guadalquivir river has to be preserved. The efforts to occupy it have to be suppressed and the creation of cross-obstructions of the road infrastructure kept to a minimum. For this, political willpower would be necessary, which would look after the precise observance of the existing extensive legislation framework: Directiva Marco de Aguas 2000/60/CEE (Water Directive), Ley de Aguas (Water Act), Ley de Costas (Shores Act), Ley de Ordenación Urbanística de Andalucía (Andalusia Urban Order Act), Ley de Protección Ambiental (Environment Protection Act), Planes Hidrológicos de Cuenca (Hydrological River Basin Plans), Directiva Hábitat (Natural Environment Directive), Ley de Espacios Protegidos (Protected Area Directive), Planes Generales de Ordenación Urbana (General Urban Order Plans), Ordenanzas Municipales (City Order), etc... and also the competency framework (River Basin Organisms, Department of the Environment; Environmental Committee, Environment Council; State Harbors, Development Department; Public Works Department; Environment Committee and Council, etc...).

Finally, the future administration of these risk area has to be guaranteed and they have to be protected with appropriate cooperation of the authorities. Such cooperation could be realized through the creation of an association for decision making and management, through international directives and treaties or by both. Definite change can be made in the concept of interference with river streams. These interferences should no longer only observe hydrological and structural objectives (building of additional protective walls, dams, reservoirs, river bed straightening, sewage systems, etc ...). Other methods, respecting the environment, should be preferred. The development should be harmonized with the preservation of the environment, so that the highest possible durability and sustainability can be guaranteed. 


\section{References:}

ALBENTOSA, L. (1989): Las aguas continentales de la Espańa peninsular. El Clima y las aguas. Con la colab. De J. M. Rubio. Ed. Síntesis, Madrid, No. 4, pp. 141-240.

BAENA, R., GARCÍA, B. (1995): Repercusiones de la intervención antrópica contemporánea sobre la llanura aluvial del Guadalquivir aguas arriba de Seville. Cambios Regionales a finales del siglo XX. Ed. A.G.E-Univ. de Salamanca. Salamanca, pp. 9-14.

BAENA, R., GARCÍA, B., GUERRERO, I., HARTVICH, F., LEICHT, B., MARCHIOL, L. (2004): Floods 2002 in Prague: reflections, lessons and ideas. Geografie-Sborník ČGS, 109, No. 2, ČGS, Praha, pp. 170-180.

BROOKES, A., SHIELDS, F. D. (1996): River channel restoration: guiding principles for sustainables projects. Wiley, Chichester, $438 \mathrm{p}$.

BOSCH, J. (1988): La Seville Islámica, 712-1242. Colecc. HȘ. Univ. de Seville, Seville, No. 92,417 p.

DAŇHELKA, J. (2004): August 2002 flood in the Czech Republic: meteorilogical causes and hydrological response. Geografie-Sborník ČGS, 109, No. 2, ČGS, Praha, pp. 84-92.

DÍAZ, F, BAENA, R. (1999): La restauración geomorfológica del río Guadiamar. International Seminary Corredores ecológicos y restauración de ríos. Seville, Junta de Andalucía, $78 \mathrm{p}$.

DRAIN, M., LHÉNHAFF, R., VANNEY, J. R. (1971): Le Bas Guadalquivir. Introduction géographique. Casa de Velásquez. Ed. Boccars, Paris, No. 1, 124 p.

GARCIA, B., BAENA, R. (1997): Cambios históricos en la hidrología del Guadalquivir y su repercusión en el meandro de Tocina (Seville). En Rodríguez, J. (ed.): Cuaternario Ibérico, (AEQUA), Seville. pp. 368-371.

GUERRERO, I., BAENA, R. (1996): La inundación del Guadalquivir en diciembre de 1996 (sector Alcolea del Río-Cantillana, Seville). En: Investigaciones recientes de la Geomorfología espańola, Geoforma Ediciones, p 25-37.

GARZON, G., ALONSO, A., LÓPEZ, J., ARCHE, A. (1990): Desbordamientos en el río Jarama (provincia de Madrid) e interferencia humana en la llanura de inundación. IV Reunión Nac. Geol. Ambiental y Ordenación del Territorio. Gijón, p. 259-270.

GIL OLCINA, A., MORALES, A. (1989): Avenidas fluviales e inundaciones en la cuenca del Mediterráneo. Instituto Universitario de Geografía, Alicante, 586 p.

JANSKÝ, B. (2004): Strategie di difensa per Praga (Strategie ochrany Prahy). In.: Governare l'acqua - Difensa del territorio, qualitŕ, tutela, servizi, emergence regionali e confronti europii. Europa e Regione 54 (Collana di studi, maggi e documentazioni). IRSE (Instituto Regionale Studi Europei, Friuli Venezia Giulia. Edizioni Concordia Sette, Italia, pp. 61-71.

LANGHAMMER, J. (2003): Antropogenic Transformation of River Network in the Otava River Basin. Acta Universitatis Carolinae - Geographica, XXXVIII, No. 2, UK, Praha, pp. 139-155.

MARTÍNEZ, R.; GÓMEZ, A., GARCÍA, J. M. (1991): Ajustes fluviales derivados de cambios de usos del suelo en el Pirineo Aragonés. Cuaternario y Geomorfología, 5, p. 91-105.

MATEU, J. (1990): Avenidas y riesgos de inundación en los sistemas fluviales mediterráneos de la Península Ibérica. Rev. Asociación de Geógrafos Espańoles, 10, 2Ș época. Madrid, $103 \mathrm{p}$.

MASACHS, V. (1954): Las aguas. Geografía de Espańa y Portugal. Ed. Montaner y Simón. Barcelona, t. 2, pp. 80-142.

NIJLAND, H. J., CALS, M. J. R., eds. (2000): River restoration in Europe. Practical approaches. Conference on river restoration the Netherlands. Ed. RIZA Wageningen, $343 \mathrm{p}$.

KLINGEMAN, P. C.; BRAVARD, J. P., GIULIANI, Y. (1994): Les impacts morphodynamiques sur un cours d'eau soumis ŕ un aménagement hydroélectrique $\dot{\mathrm{r}}$ derivation: le Rhône en Chautagne (france). Revue de Géographie de Lyon. 69, No. 1, pp. 73-87.

PARKER, D. J., PENNING-ROWSELL, E. C. (1982): Flood risk in the Urban Environment. Geography and the urban Environment. V Jonh Wiley and Son, Chichester, p. 201-239.

PEIRY, J. L., NOUGUIER, F. (1994): Le Drac dans l'aglomeration de Grenoble: premičre evaluation des changenments géomorphologiques contemporains. Revue de Géographie Alpine, 82, No. 2, pp. 77-96.

SCHUMM, S. A (1977): The fluvial system. John Wiley and Sons, London, 338 p. 
UNESCO (1971-1985): Discharge of selected rivers of the World, III. UNESCO Press, Paris.

VANNEY, J. R. (1970): L’hidrologie du bas Guadalquivir. C.S.I.C. Madrid, 176 p.

WARD, R (1978): Floods. A geographical perspective, London, MacMilan, 224 p.

Shrnutí

\section{SROVNÁVACÍ ANALÝZA POVODNÍ V PRAZE (ČESKO) A V SEVILLE (ŠPANĚLSKO): POSUZOVÁNO Z GEOGRAFICKÉHO HLEDISKA}

Řeky představují příklad komplexního ekosystému hluboce pozměněného rozmanitými aktivitami člověka. Současně mají pro města ležící na jejich březích značný význam ekologický, sociokulturní a ekonomický. Území v bezprostředním okolí tokủ nebývá však často integrováno do územního rozvoje měst vzhledem $\mathrm{k}$ nebezpečí záplav $\mathrm{s}$ katastrofálními následky. Záplavové území představuje tak konfliktní prostor mezi př́írodní a socioekonomickou sférou. Přesto v územích ohrožovaných povodněmi roste urbanizační tlak, podmiňující vznik nevyvážené situace mezi řekou a městem. V takovém prostředí se zvyšuje riziko potenciálně nebezpečných extrémních hydrologických jevů.

Předmětem článku je diskuze různých strategií protipovodňové ochrany, které jsou využívány $\mathrm{k}$ prevenci předvídatelných povodňových rizik pro území Prahy a Sevilly. Pro ilustraci těchto ideí zvolili autoři analýzu dvou velmi odlišných povodí - Vltavy, reprezentující středoevropský tok v mírném kontinentálním klimatu s typickým fluviálně - niválním režimem odtoku, s maximy průtoku v době jarního tání sněhu a Guadalquiviru, jako hlavního kolektoru jižního Spanělska, s charakteristickým klimatem mediteránního typu a fluviálním odtokovým režimem se zimními průtokovými maximy.

Z hydrologického a morfologického hlediska je na základě porovnání povodně v Praze v roce 2002 a srovnatelně velkých povodní na řece Guadalquivir v Seville (např. v letech 1963 a 1996) patrné, že především existence člověka a jeho aktivit v záplavovém území dává povodním katastrofický a mimořádný charakter. Je třeba připustit, že povodně takové velikosti a charakteru (5 $160 \mathrm{~m}^{3} / \mathrm{s}$ na Vltavě resp. $5700 \mathrm{~m}^{3} / \mathrm{s}$ na Guadalquiviru) se mohou opakovat, tím spíše, když uvážíme, co je hlavní prríčinou nestability - tzn. změny obou fluviálních systémů a jejich hlavní kontrolní faktor, tj. podnebí.

Jde především o to, abychom u obou řek našli východiska $\mathrm{k}$ realizaci integrálních strategií, tedy nejen strukturálních opatření vyžadujících vysoké finanční náklady, jako je to$\mathrm{mu} \mathrm{v}$ případě Sevilly. V záplavovém území podél tokủ bychom měli plánovat a územní strukturu uspořádat tak, aby se přizpůsobila přírodní hydrologické a morfologické dynamice a ne naopak. Rece bychom tedy měli ponechat její přirozený volný prostor. Zkušenosti však ukazují, že společnost ignorovala tyto zásady a redukce nestabilních záplavových území přinesla výrazný růst ekonomických nákladů, materiálních škod i obětí na životech.

V případě Vltavy v Praze chybějí vysoké strukturální investice v té podobě a objemu, jak byly vynaloženy v Seville, což je dosud neobvyklé i v jiných městech střední Evropy. Dá se přitom předpokládat, že se protipovodňová ochrana soustředí především na úsek Vltavy mezi Vyšehradem a Letenskými sady vzhledem $\mathrm{k}$ vysoké historické a kulturní hodnotě tohoto území. To předpokládá ovšem úzkou vazbu na výše i níže ležící záplavová území, která přispějí díky plánovaným rozlivům ke snížení piků budoucích mimořádných povodňových vln. Jednou $\mathrm{z}$ takových možností je např̀. obnovení funkce starého opuštěného ramene Vltavy v Karlíně. V každém případě lze konstatvat, že zajištění ochrany v historické části města přenáší problémy protipovodňové ochrany do jiných inundačních území.

V programu „Prevence před povodněmi“, schváleného českou vládou, se mimo intravilány obcí počítá $\mathrm{s}$ výstavbou polderů a malých vodních nádrží, které zvýší kapacitu regulace toků. Na území Prahy byly podél břehủ Vltavy vymezeny zóny vysokého povodňového rizika a schváleny nouzové plány navzájem koordinované rưznými orgány státní správy. V některých úsecích toku, především na pravém břehu podél Karlína a na levém břehu kolem Holešovic, byly dobudovány protipovodňové stěny.

$\mathrm{V}$ případě řeky Guadalquivir na průtoku Sevillou bylo provedeno větší množství strukturálních opatření, které zachovaly současnou rovnováhu v rámci nestabilního systému řeka - město. Do budoucna se plánuje ochrana rozlehlé nížiny nad městem , která bude vodohospodářsky propojena s umělým kanálem Guadalquiviru. To zabrání obsazení ŕíční nivy rozmanitou novou infrastrukturou. $\mathrm{K}$ tomu bude však zapotřebí politické vůle a dodržování patřičných legislativních norem. 
Obr. 1 - Hlavní povodně v historii měst Praha (Vltava) a Seville (Guadalquivir)

Obr. 2 - Srovnání hydrologického maxima na Vltavě v letech 1890 a 2002

Obr. 3 - Srovnání hydrologického maxima na Guadalquivir v letech 1963 a 1996

R. Baena Escudero and I. Guerrero Amador are with University of Seville, Faculty of Geography and History, Department of Physical Geography and Regional Geographical Anylyses. B. Jansky is with Charles University in Prague, Faculty of Science, Department of Physical Geography and Geoecology, Albertov 6, 12843 Praha 2, Czechia; e-mail: jansky.b@seznam.cz,baena@us.es, inmaguer@us.es.)

Arrived to the editorial board on August 28, 2006 